\title{
YOUR HISTORY, MY NARRATIVE: UNCOVERING ME THROUGH YOU
}

\author{
NAWAR AL-HASSAN GOLLEY \\ American University of Sharjah (UAE)
}

This paper examines three books, Khul-Khaal ${ }^{1}$, Doing Daily Battle ${ }^{2}$ and Both Right and Left Handed ${ }^{3}$, all of which were published in the 1980s. Their subtitles, Five Egyptian Women Tell Their Stories, Interviews with Moroccan Women and Arab Women Talk About Their Lives respectively, indicate that all three books contain life stories of women from Arab countries. These books, then, fall into one category, not only because of their subject matter but also because they raise similar sets of questions relating to their technique and conditions of production.

The paper offers a critique of the process of stereotyping and generalization drawn from these anthologies by the authors/editors themselves, as in KhulKhaal, and comment on how readers also tend to generalize even without editorial prompting (a process discussed later when analyzing the other two texts). Nonetheless, these same texts, read carefully, can be potentially good sources of knowledge. This paper does not read these anthologies ethnographically, that is, it does not take the interviewee as typical of Arab culture, which is known to be too complex to be represented by these women alone. However, some conclusions, which necessarily entail some kind of generalization, about how a common culture affects self-image, can be drawn. Common culture here does not refer to a monolithic Arab culture as such but to the similar social and economic conditions which some of the women share. This paper also examines how class and economic positions interact with gender in these anthologies and produce different forms of oppression. Any

1. AтIYA, Nayra: Khul-Khaal: Five Egyptian Women Tell Their Stories, London, Virago, 1988, hereafter Khul-Khaal.

2. Mernissi, Fatima: Doing Daily Battle: Interviews with Moroccan Women, Mary Jo Lakeland (trans.), London, The Women's Press, 1988, hereafter Doing Daily Battle.

3. ShaAban, Bouthaina: Both Right and left Handed: Arab Women Talk About Their Lives, London, The Women's Press, 1988, hereafter Both Right and Left Handed. 
generalizations in this paper should not be harmful nor should they entail the risk of stereotyping involved in the cruder kinds of ethnographic reading.

\section{TEXTUAL STRATEGIES: CONTROL AND DIALOGUE}

To start with, each of these books is multi-authored, in the sense that each one contains life stories of the interviewees and of the interviewer herself to different degrees. Although they are multi-authored, only one name is presented on the cover of each book as the writer. This is justified in so far as the interviewed women did not themselves write their stories but told them, orally, to the interviewers. Nor did they initiate the telling of their stories, without which these books would have been impossible; their stories were instead solicited by academic Arab women, Nayra Atiya, Fatima Mernissi and Bouthaina Shaaban respectively, whose names we read under the titles of the books. These books are also multi edited, or at least doubly edited. Selectivity, which is necessarily practiced by any person who decides to record personal autobiography or memoirs, is here imposed according to specific criteria upon the interviewed women who, at the request of Atiya, Mernissi and Shaaban, answered certain selected questions about their lives. This is not to deny that the women themselves also, consciously or unconsciously, practiced selectivity. For they too must have chosen what to reveal in their answers and what to keep hidden. Generally speaking, all people exercise a strategy of deciding what to say depending upon whom they are addressing or who is likely to read or hear them.

The question of the implied or intended audience is especially relevant to these books. For they all are edited, structured, produced and translated, in a word, textualized for potential western readers. But the books have not been published in Arabic at all; Atiya and Shaaban translated the interviews and published them in English. Mernissi originally wrote her book in French, which was later translated for English readers by Mary Jo Lakeland. The way in which each individual book is textualized is examined later. For now, I want to argue that the fact that these books were published in English and French make them more ethnographic material than simply life stories of Arab women. I use the term "ethnographic» not in the sense that the interviewed women are taken by Atiya, Mernissi or Shaaban to be the "savage», "primitive» or "tribal» "others» who are the subjects of many ethnographic studies. The authors/editors intention cannot be said to be the same as that of a western ethnographer who merely seeks the knowledge of an "other», usually perceived as "inferior", for private or public reasons, or both. For besides wishing to display some kind of an alternative knowledge to western readers, the editors of these anthologies also aim, as their first objective so they claim, to allow a public «voice» for the women who have been unrepresented or underrepresented. An English or French reader is still bound to read the interviewed women as "exotic others", however, and thus read their stories ethnographically.

Whether intentionally or not, these books are made polemical. On the one hand, the titles and sub-titles present the books as stories of individual 
Arab women; in their introductions, the interviewers themselves declare their objective of wanting to break the silence of the underprivileged by allowing them a voice through which each of them can express herself freely and publicly. On the other hand, another objective for Atiya, Mernissi and Shaaban, as they themselves admit, is to reveal to western readers their limited and mystified knowledge of Arab women. These works include the stories of many women, from the illiterate to the professional (in Atiya's book there are no professional women as such, but two women went to preparatory school). The writers of these books, especially Shaaban, hope to show the diversity of conditions of Arab women and to present them as powerful and always struggling to better themselves by the means available to them, in contrast to what has been believed about them in the west. Demystifying the harem, which (except in some areas) nowadays hardly exists beyond western fantasies and discourse, is one of the main aims of these texts. Thus, these books offer a kind of knowledge about Arab women in general. The voices of these women cease to be voices of individual women; their stories are presented to be read and remembered mostly as typical of Arab women.

The number of women whose life stories are included in each book also contributes to their typification. Five women are interviewed in Khul-Khaal, twelve in Doing Daily Battle and several dozen in Both Right and Left Handed. It becomes difficult for the reader to remember whose story is whose, either because the stories are so similar, as in Atiya's book, or because of the large number of women who are assigned limited space for their stories (as in the other two books). Moreover, the names of the women in Khul-Khaal are concealed under false ones, which makes them even more into types rather than individuals to be distinguished by their real names.

Furthermore, the nature of these books is dialogic: they are based on the question/answer model of interviews. Atiya, Mernissi and Shaaban have conducted "discourses», an adequate term for such interviews borrowed from Emile Benveniste, whose definition of discourse as «a mode of communication in which the presence of the speaking subject and of the immediate situation of communication are intrinsic ${ }^{4}$ is relevant to my reading of the three texts. According to Benveniste's definition, discourse should not be read outside its specific situation or occasion in which «a subject appropriates the resources of language in order to communicate dialogically $»^{5}$. The women, in their answers, did not transcend the immediate context and the limited situation in which dialogues were communicated through language. The use of «I» (which necessarily implies a "you»), and of other deictic indicators, such as "this», "that", "now», and so on, signals "the present instance of discourse rather than something beyond it ${ }^{6}$. In Benveniste's sense, then, discourse cannot or should

4. Quoted in CuIfFord, James: The Predicament of Culture: Twentieth-Century Ethnography, Literature and Art, Cambridge, London and Massachusetts, Harvard University Press, 1988, p. 39

5. Ibid., p. 39.

6. Ibid., p. 39 
not be interpreted outside its situation. But Atiya, Mernissi and Shaaban did interpret the interviewees' discourses through the process of transforming them into texts. This process is called textualization, which is defined by James Clifford as a process through which unwritten behavior, speech, beliefs, oral tradition, and ritual come to be marked as a corpus, a potentially meaningful ensemble removed from an immediate discursive or performative situation? ${ }^{7}$.

Textualization, then, is the shaping and preparation process which precedes interpretation of a discourse. I want to add to Clifford's comments, that the process of textualization implies within it some kind of a conscious or unconscious generalization and typification, which also might lead to falsification. A textualized discourse may be turned into evidence of a generalized context, a cultural one. The textualization of the dialogic mode makes a type of a person. The subjectivities of the interviewed women are dissolved in the texts, but to varying degrees. In Khul-Khaal, textualization is taken to its extreme, whereas preserving the format of question and answer, as in the other two books, limit the extent of the process of textualization.

Before examining the extent of typification through textualization in each book separately, I want to argue that the convention of these kinds of texts (which are based on orally told stories conducted through interviews) was used by ethnographers as early as the nineteenth century. This method became valuable to anthropologists because it gave "the imprimatur of authenticity to their observations of the lifestyles» of the various "native» groups ${ }^{8}$. An American Indian, for example, may be interviewed over a period of time by a "white» ethnographer (who sometimes lives in the same household or nearby and probably learns some of the Indian's language) for the purpose of publishing a book, presenting it as the memoir or the autobiography of the interviewed Indian as written by him/herself. ${ }^{9}$ The question/answer model is, of course, repressed in a first-person narrative, and the narrative is usually supplied with many footnotes and pictures as well as forewords, introductions, appendices and glossaries, usually with the help of a translator whose role is equally obscured. The interviewer who is also the editor and probably the translator, denies any significant interference, and, in effect, effaces him/herself in an attempt to claim full neutrality, sincerity and authenticity in the disguised descriptive ethnography. Atiya's text fits adequately in this structure (explained later).

Recent ethnographers, who have realized the need to announce themselves as the actual writers and interpreters of such so-called autobiographical accounts,

7. Ibid., p. 38.

8. In Helen CARR's «Native American Women's Autobiography», p. 2, who was kind enough to post me a copy of her article before publishing.

9. Examples of such autobiographies: JACKSON, Donald (ed.): The Life of Black Hawk: An Autobiography, Urbana, University of Illinois, 1933; BARRETT, S. M. (ed. 1906), newly edited by Frederick W Turner III: Geronimo: His Own Story, London, Abacus, 1974; LuRIE, Nancy O. (ed.): Mountain Wolf Woman: Sister of Crashing Thunder, Ann Arbor, Michigan University Press, 1961. 
keep the basic interview model in the final production of their texts. Presenting the discursive process in the form of a dialogue between two individuals somehow balances the authority of the ethnographer, it is claimed. That is, it gives a voice to the interviewee, whose knowledge as the other is sought, a voice which is no less distinct than that of the interviewer. This new mode is supposed to lessen the ethnographer's authoritative representation of the "other»; it does not completely stop typifying the "other» as a representative of a culture, however, although it does so to a lesser extent than in the repressed dialogic model. An example of such recent ethnographic material is a book called Tuhami: Portrait of a Moroccan (1980) written by Vincent Crapanzano who questions ethnographic authority from within the discipline ${ }^{10}$.

Although these texts under examination are not written for ethnographic disciplines, in form, at least, they fit in this area. Like ethnographic books, these kinds of texts have had an increasing market in the west since the 1950s and form a new type of knowledge for westerners who for centuries have been studying and speaking for the rest of the world. Their classification as books on social conditions of women in Arab countries brings them even closer to ethnography. Technically speaking, Atiya's book fits in the first model whereas Mernissi's and Shaaban's books fit in the second. One main difference between ethnographic writing and the texts I am reading is that the writers of these texts are not foreign to the areas where they are conducting their interviews. They are western-educated Arab women. Their intention to present their material to westerners however, makes their situation almost similar to that of American and European ethnographers who seek knowledge of what they usually see as (inferior) "other» cultures. Although the women interviewed in these books are not "the other» as such for Mernissi and Shaaban, they are so for Atiya, who went to Egypt as an adult woman from the United States. But of course, even within one geographic area, "the other» may be constructed through class, education and dialectal difference.

\section{KHUL-KHAAL: REPRESSED DIALOGUE}

Khul-Khaal was first published in 1982 by Syracuse University Press in New York, and was republished by Virago in London in 1988 with an afterword by Nawal el-Saadawi (references here are to the London edition). The book also has a foreword by Andrea B. Rugh, a professional American anthropologist, who reads the book from this standpoint. These stories "provide a mine of information for anthropologists and others seeking an understanding of Egyptian culture», she comments. This has been stressed by Saadawi who reads the five women as "typically Egyptian». Rugh makes generalizations from these five stories about "Muslim women" at large, although one of the Khul-Khaal women is Christian. She concludes from her reading, for example,

10. Crapanzano, Vincent: Tuhami: Portrait of a Moroccan, Chicago and London, The University of Chicago Press, 1980. 
that «the possibility men have to divorce fairly easily, however remote that eventuality, hangs like a cloud over the heads of Muslim women» ${ }^{11}$, as if all Muslim women were living in fear of divorce and there were no Muslim women who would prefer a divorce to a marriage they were not happy in. Rugh also repeats some of the women's claims that «[m]oney and sex are the most basic problems discussed among Egyptian women $»^{12}$, as if it were the ultimate truth. Referring to Dunya's first husband, Hagg Ali, Rugh calls him, instead, the Libyan four times in her foreword; this makes him more of a stereotype than an individual.

Rugh does criticize western generalizations about «eastern people», for example that they have a «fatalistic nature» or that their women are "suppressed» and "passive»; she explains that reading Khul-Khaal will correct some of the misrepresentation and misunderstanding of Egyptian and «Muslim» people. Rugh goes on, however, to romanticize the stories of the five Egyptian women. According to her, these women have "extraordinary natural perception about the world in which they live» ${ }^{13}$, and they are philosophers. Such condescension is an underestimation of these Egyptian women although Rugh is trying to prove the opposite. The term «natural» in itself implies underestimation, and calling them "philosophers", when they are being commonsensical implies that they are not even expected to have common sense. These women are «talented storytellers", but again Rugh generalizes this into a characteristic "particularly developed among the folk of Egypt ${ }^{14}$. The term "folk» romanticizes, generalizes, and dehistorizes.

Rugh, then, reads Khul-Khaal as "an encounter with a new culture» ${ }^{15}$. In her attempt to present the book to western readers, she makes Dunya, Suda, Om Gad, Om Naeema, and Alice stand for Egyptian, if not Muslim women: the names of these women, false anyway, do not matter any more. Instead of reading these accounts as life stories of individual women, the reader is led to generalize from them a knowledge about the culture that these women are made to exemplify.

Atiya was born in Egypt, but moved to the United States at eleven, only to return to Egypt as an educated adult woman at thirty-three. Although she spoke Arabic, Egyptian society felt strange and foreign to Atiya. Writing KhulKhaal was her way of understanding Egypt. In her «Preface», she writes:

«I felt I was being allowed a privileged peek into a society I knew almost nothing about and which I longed to understand, as much as I longed to become intimately acquainted with an Egypt I had left to go to the United States some twenty-five years earlier ${ }^{16}$.

11. ATiYa, Nayra: Op. cit., p. 12.

12. Ibid., p. 12.

13. Ibid., p. 7.

14. Ibid., p. 8.

15. Ibid., p. 19.

16. Ibid., p. 23. 
Although she is not an anthropologist herself, Atiya's situation is similar to Rugh's; for she, too, seeks knowledge of Egyptian society. Atiya denies that the five women are "representative of all Egyptian society" or "any particular social class or type of person $\aleph^{17}$. But among all the stories that she collected on her tapes, she chose the five that touched her most, whose "richness of detail ... added perspective to [her] efforts to understand Egypt and [her] people» ${ }^{18}$. Atiya's selective and emotional reaction, which is different from the objective stance of "knowledge", indicates that these women are typified, to herself most of all, for through their stories she claims to have understood Egypt and Egyptian people and from them draws a number of generalized conclusions. Atiya includes forty photographs in her book, which, she says, do not identify the five women, but are meant to illustrate the texts. The reader looking at the photographs of men, women and children is liable to take them as being representative of Egypt. The photographs, then, add to the process of typification.

Atiya tape-recorded these stories over a span of three years (1976-1979) yet the idea of publishing them is supposed to have been suggested by Rugh. Atiya also claims detachment from the stories: she says that she does not wish to make an analysis but prefers to leave the task for anthropologists and sociologists. Such a claim tends to conceal that the stories are her production more than anybody else's and that interpretation is already implied in her very writing and translation of them. Atiya did not have the women tell her their stories in one session. As she herself said, she met these women on many occasions, during which she recorded incidents and episodes of their lives. Yet Atiya collected and combined these elements as if they were "narrated» as complete stories. She admits editing the stories before translating them into English. Translation in itself changes a great deal: it «may render bizarre, exotic, downright irrational what would have been ordinary in its own context» ${ }^{19}$, as Crapanzano argues. Atiya's interpretation is carried out within a complex process of, first, asking certain questions, second, editing fragmented stories, third, translating them and, finally, producing the book Khul-Khaal.

The sub-title of the book, Five Egyptian Women Tell Their Stories, reads as if these women actually told their stories themselves. In spite of all the efforts to convince the reader that the book is a spontaneous telling of women's lives as they were told, however, the book is clearly Atiya's intended version of such stories, which should be kept in mind for any kind of reading.

\section{DOING DAILY BATTLE: TRANSPARENT DIALOGUE}

Mernissi presents Doing Daily Battle in a much more straightforward way than Atiya. The sub-title is not disguised, it simply says Interviews with Moroccan Women, which conveys the real nature of the book. Unlike Aitya, Mernissi

17. Ibid., p. 28.

18. Ibid., p. 28.

19. Crapanzano, Vincent: Op. cit., p. 8. 
keeps the question/answer model in her final production of the book. Mernissi, herself a sociologist, does not try to efface her personal motives nor herself for that matter. She declares, early in her introduction, that the objective of the book is to break the ancestral silence of Moroccan women, but also to see how Morocco appears through the words of its women. The implication is that the book is intended as knowledge about twentieth-century Moroccan women, but with no denial by the writer herself. It is meant to show the reader, first, that the harem time is almost over-only one of the twelve women, Batul Binjallna, spent her life in an actual harem-and second, that Moroccan women have a different story to tell about their lives and about their society than that told by men. But who is this knowledge addressed to?

Having been first written in French, then translated into English, Doing Daily Battle is clearly addressed to western readers. The introduction and the footnotes give details to readers who are presumed to know either very little or nothing or who have distorted knowledge of Morocco. The "Glossary» is particularly addressed to those who know no Arabic at all. French is widely spoken among the Moroccan educated elite, who also are potential readers of Mernissi's book. As a rhetorical device, and as a way of anticipating "his» response, Mernissi pretends to address herself particularly to an intended reader, who belongs to this last group, whom she calls "Mr. Terrorist», and who, she claims, would reject her book on the basis that the interviewed women are not representative of Moroccan reality. "Mr. Terrorist» stands for the men who monopolize the symbolic values of Arab societies. "Terrorist tactics» are adopted by these men, according to Mernissi, whenever a woman stands up to express herself, either by stopping her or by denigrating what she says. Mernissi explains to these men, who also reject feminist ideas as «imported" and hence contradictory to the local "cultural heritage", that although her women are not claimed to be representative of Moroccan women, their stories are real and true. Many "terrorist» men in other Arab countries speak only Arabic, however, and would not have Mernissi's message passed on to them.

While Atiya tries to conceal herself in her book, Mernissi avoids selfeffacement in two ways. First, she introduces herself fully to the reader, summarizing her own story, unlike Atiya who keeps herself unknown to the reader except for the publishers' eleven-line summary of her life. By telling her story, Mernissi equates it with the stories of the women in her book, while Atiya looks detached and aloof. Second, Mernissi does not try to disguise herself by omitting her questions and diffusing the dialogue into a first person narrative, as Atiya does. Mernissi even admits that she was not objective in her attitude towards the women she interviewed: most of them were illiterate, and she says that she had a special affinity with them because she remained illiterate herself until the age of twenty. Mernissi refers disapprovingly to the objectivity of the "research technique» she was taught in French and American

20. MernissI, Fatima: Op. cit., p. 19. 
departments of sociology and anthropology. She also admits her «intervention in the preparation of the words of interviewees for the printed page $»^{20}$.

By preserving the question/answer model, Mernissi preserves some authority for these women and also some sense of identity. The answers are not taken out of context nor are they generalized into complete stories. Thus, these women are not presented as typical as are the women in Atiya's book. Mernissi's aim of depicting the stories of the women as facets of Moroccan reality, and not as the Moroccan reality, can be said to be achieved.

Mernissi considers her book an initiative towards understanding herself as well as the women she interviewed. This claim may very well be true, and I do not wish to dispute it. In fact, most people who have done this kind of research claim that they themselves go through a process of self-examination and selfunderstanding during and after the interviews. Crapanzano, for example, admits that he learned much about himself and his world through his encounter with Tuhami, and argues that fieldwork of this kind must be understood as a process of continual discovery and self-discovery ${ }^{21}$. The point I would make in relation to Mernissi's claim, however, is that she gives no tangible evidence for the reader to see her self-discovery taking place in the pages of her book. In other words, she does not translate for the reader the process of self-comprehension that she claims is taking place in her consciousness, whereas the third book I want to consider does exactly this.

\section{BOTH RIGHT AND LEFT HANDED: INTEGRATED DIALOGUE}

Shaaban presents her book, Both Right and Left Handed published in 1988, as part of her struggle for "mutual self-discovery among women ${ }^{22}$. She achieves this not only by telling her own story, and with more details than Mernissi, but by full reciprocation in her conversation with the women she meets. Conversation is a more adequate term to describe Shaaban's dialogue with the women than interview, because although she, like Mernissi, preserves the question/answer model, she does so in a narrative mode. Mernissi registered her interviews in a formal and journalistic way, identifying questions with the letter "Q" and answers with "A». Shaaban preserves the dialogic mode as a novelist does. Technically speaking, her book reads as an autobiography. Shaaban herself can be read as the main character who is seeking self- understanding by the detour of comprehension of other women, the other characters. Unlike Atiya and Mernissi, Shaaban tells the reader about the setting, time and place, of her conversations with the women and explains when and through whom she met them. She describes the women themselves, how they dress, how they behave, and what they feel. She even introduces side plots, like quoting the conversation she overheard at the bus stop between two unknown women.

Above all Shaaban reflects upon herself. Every now and then, she makes flashes back on her own life and her relationship with her husband and her

21. Crapanzano, Vincent: Op. cit., p. 138.

22. ShaAban, Bouthaina: Op. cit., p. 2. 
family, by narrating an incident or by comparing her own situation to those of the women she talks to. This technique makes Shaaban equal with the women she meets, more so than Mernissi. Apart from being the writer of the book, Shaaban does not seem to be practising authority which could make the women look like inferior others, whose stories are narrated with fascination and an awareness of difference as in Atiya's book. The women in Shaaban's book (as in Mernissis's book) might still be read as more typical than individual because Shaaban too selects the theme questions; however, the large number of women and the diversity of their stories make them more representative of their societies than, say, five Egyptian women whose stories are presented as almost the same.

There are also situations where Shaaban is engaged in a conversation with more than one woman at a time. This makes her book a real «attempt to enable a number of women caught up in a burning moment in history to share experience with others ${ }^{23}$. Shaaban, though, has in effect limited the audience that could share her experience and those of the women in her book to English readers. Her stated purpose in publishing the book is:

«...to enable other Arab women and Western women to share something of

my experience, and to hear for themselves the voices of these women-fighters and professional, politicians, devoted wives and faithful mothers of martyrs.» ${ }^{24}$

But, of course, the number of Arab women who can read English is very limited; the majority of them will not be able to share the experience Shaaban wants them to. This point applies to all three books discussed in this paper. Atiya, Mernissi and Shaaban have limited the effect of their books by not publishing them in Arabic, a language they all know very well. Yet there are some publishers, such as Al-Saqi Books in London, that support feminist writing and publish such books. Had they been available in Arabic, these books could have contributed to the cause of Arab feminism. Reading these books in an context, given their potential value, would have fewer of the problematic aspects of the ethnographic use discussed above.

\section{SHAPING THE DIALOGUE: THEMES}

Thus, the themes around which these three books center cannot be voluntarily and freely chosen by the women interviewed, but are consciously and knowingly selected by the writers of these books. Rugh tries to absolve Atiya of deliberately choosing the themes of marriage, death, and circumcision, claiming that "the vivid details of these events have naturally flowed out of the narrative, not selected by [Atiya], but chosen by the women themselves as the subjects around which to organize their discourses» ${ }^{25}$. In Atiya's "Preface», however, we sense some kind of confession that she herself chose these topics,

23. Ibid., p. 2.

24. Ibid., pp. 1-2.

25. АтाYA, Nayra: Op. cit., pp. 221-22. 
which run through Dunya's story, the first woman Atiya interviewed. Atiya, fascinated by the experiences that Dunya went through, chose to «round out» these common experiences by making them the centre of her intended book. Mernissi does not deny that she aims in her book to see how the Moroccan women perceive "three phenomena: sex roles, the marital couple, and contraception $»^{26}$. Her questions are directed towards these issues.

In Shaaban's book, the topics are varied and carefully chosen according to each woman's educational background. Unlike Atiya and Mernissi, Shaaban did not ask the women she met only about their personal lives, but brought them into serious discussions about different issues. There are discussions on family upbringing, inter-family and arranged marriages, motherhood, heterosexuality and homosexuality, relations between husbands and wives, mothers and sons and daughters, traditions, religions, education, professions and careers, the law, politics, feminism, the dichotomy between the private and the public and between theory and practice, comparisons between the position of western and Arabic women, and so on. The women include the illiterate and the highly educated, those who work as mothers and wives only and those who combine professions with these roles, the young and the old, the submissive and the rebellious or the feminist, the liberal and the militant. The intention here is not to set these books up along a spectrum of truth/falseness as such, but to show how they differ not only in form (as explained earlier) but also in content.

There are no complete life stories in these anthologies; there are rather extracts of lives. Each woman is interviewed within a limited time, and a limited space is assigned to each woman's story. Moreover, the type of questions addressed to each woman dictate what she tells about her life. Hence, questions related to the representation of self in relation to memoirs and autobiographies cannot be examined in relation to the short extracts in these anthologies. Although the stories are fairly short and organized in accordance with certain questions, it is still possible to look at the issues these women raised in their accounts and also the issues raised by the way they presented their accounts or the way these accounts have been presented for them by the editors.

The "voices" of these women can be read as calling for political action and change, when they talk about the necessity of education, when they complain about their arranged marriages and when they publicly describe certain sexual practices which contribute to their oppression. Their spelling out of sexual issues can be read as an act of publicizing what is perceived in their societies to be the most "private» and taboo of all matters. The practice of female circumcision and the ceremony of the bride's defloration both performed in a semi-public way is a contradiction in a society which considers sex a taboo question. Spilling the female child's blood at circumcision, and displaying the bride's virgin blood at defloration turns the female body into an object of

26. Mernissi, Fatima: Op. cit., p. 5. 
control and a device to publicize the honor of the family in its men's interest. In these anthologies, the women publicize these "private» issues, by talking about them too, but in this case, in their own interest.

\subsection{Change Through Work and Education}

Most of the women who "speak» in these books and who are illiterate and of working class positions, do not offer a strong sense of individual self in the western sense of the term, though as noted later there are signs of selfreflection on their position. That is to say, they do not talk of themselves as independent individuals or of their lives as being of their own making, although it must always be remembered that a different impression might have been produced come had they been asked different questions. These women often attribute their "miserable» lot to fate or destiny in accord with conventional religious teaching. However, they do not seem to be totally submissive to such fate, for they themselves acknowledge the need for change through education and work, and there are moments when they appeared to aspire to a way of distinguishing themselves from others. Aware that if they sit at home without work their poor families or husbands cannot look after them, these same women go to look for work everywhere, no matter how far from home, in contrast to the traditional role, assigned by middle and upper class men, which confines women's work to the private realm of the household.

Learning a skill or a trade is essential for most of these women's and their children's survival. For some women, paid work is necessary for more than just survival. Nazha, for example, could not have continued her education had she not worked during vacations and after school hours. Necessity is, however, not the only reason why some of these women go out to work. Dawiya alFalilia (born in 1913 in Morocco), did not like her second husband preventing her from working outside the home, although he could afford a comfortable life for her. For her, work was a means of socialization and integration with different people ${ }^{27}$. Suda, a Sudanese Egyptian, did not mind doing any type of work, even work as a maid, a job which she had to deny doing because her male guardians considered it "shameful». For Suda, any job is good as long as it gives her a "clean piaster». Work provides her with economic independence which gives her the right to choose when and whom she will marry. For these women, whether it is to spare them the humiliation of begging or dying of hunger, or to support their education, or even just to be able to communicate and socialize with more people, paid work provides them with some kind of independence, authority and respect, making them less liable to be oppressed and exploited by their men. Om Gad, for example, who helps her husband at the garage workshop, is the manager of the household financial affairs. Every

27. Mernissi, Fatima: Op. cit, p. 94.

28. Om Gad reminds me of my own mother, who is also illiterate, who, although she has never worked outside the home, has looked after her husband's and children's welfare with amazingly successful management using the limited income of my (educated) father. 
now and then, her husband gives her all the money they have made, and she looks after the spendings and the savings. Had he not trusted her ability to do so he would never have given her control of the family's finances ${ }^{28}$.

Speaking in the 1970s and 1980s, these women are also aware that education can provide them with better paid jobs and more humane conditions at work. Those who missed the chance of going to school are very keen on their children's education, for both sons and daughters. Dawiya admits that when she was young she did not know that education was important for her daughters; she did not enrol the eldest and accepted that the younger should leave school because she did not seem to be interested and because Dawiya thought that education would not help her daughters to find a job. But later she realizes that "an educated girl is somebody. A trade is also useful, but an education is more important $»^{29}$. For Zubaida, too, education makes «somebody» of a girl. She was forced to leave school at the age of eleven, so she was trying hard to ensure that her daughters continued their education. For Alice, education and having a profession, for a woman, mean "not only self-support but a chance to have a say in things that matter to her $\aleph^{30}$. Among the working classes especially, this interest in education is part of a rising consciousness which is rapidly spreading even in the remotest areas in the Arab countries. It is surely a great help and hope for Arab feminism; for education helps people to question conditions that they would have taken for granted before.

The educated women are, first, more conscious of themselves and of what they have achieved, and second, more gender-conscious than their illiterate sisters. Abla, for example, is proud to have got her academic job in the History department in Damascus University in 1947 when most urban middle and upper class girls were doomed to «suffer the boredom of spending their time in total isolation at home waiting for eligible husbands» ${ }^{31}$. Abla talks about social discrimination against women in every field and criticizes «the degrading and outdated laws» of the country. She acknowledges the improvement in women's position since the seventies, but pleads with all women to continue the struggle for «real equality».

Makboula Shalaq is a lawyer who made history by being the first Syrian woman university student in 1941. She criticizes the dichotomy between what men preach and what they practise. Like Abla, Shalaq admits that Syrian women have proven their capacity and creativity in every field, yet they "are still regarded first and foremost as cooks and cleaners and only secondarily as creative workers» ${ }^{32}$.

Thorea Hafez is proud to talk about her participation in the nationalist struggle for women's rights. She tells the story of the time in 1943 when she gathered with other women in the main square in Damascus and they publicly

29. MeRnissi, Fatima: Op. cit., p. 104.

30. AтাYA, Nayra: Op. cit., p. 39.

31. ShaAban, Bouthaina: Op. cit, pp. 32-33.

32. Ibid., p. 45. 
took off their veils ${ }^{33}$. Hafez compares the past and the present and sees that Syrian women have achieved complete equality, especially now that the law has been reformed to women's advantage. She goes on to draw a rosy picture of the situation. Hafez is, of course, talking from her upper class position and overlooks the situation of other women whose poverty can prevent them from deploying the law on their side. This point is raised by Amal, a law student, who thinks that the law in Syria is «illiberal», remote from social reality and biased against women as all the judges are men. Amal also sees that the main problem that Arab women suffer from is the dichotomy of "what seems to be and what actually is, of our public and personal lives» ${ }^{34}$.

\subsection{Family, Class and Feminist Consciousness}

To say that the more educated have more feminist consciousness is not to say that the illiterate women are not aware of any kind of oppression related to their gender. Malika, for example, who was never enrolled in school, sees marriage as an institution where women are oppressed, although she expresses it in her own simple terms. Had her father been alive (the father stands for social and emotional security as discussed below) and had she had a well-paid job, Malika says that she would never have wanted to get married. She prefers to work for her mother and herself rather than to serve a husband ${ }^{35}$. However, what we notice from the illiterate working class accounts is that they are more aware of the problems they suffer as poor people rather than as women. In other words, class-consciousness is more striking than gender consciousness in their accounts. Om Gad's class-consciousness, for example, is clear in her argument about her daughter's marriage. She wants her to marry a man of their own class; she does not want a middle or upper class son-in-law who would ridicule and humiliate them ${ }^{36}$. Om Gad's gender consciousness is very limited. There are a lot of stereotypical statements in her story. She thinks that her son is "a real man» because nothing moves him $^{37}$ and that «men are never afraid» ${ }^{38}$. Om Gad is aware that "a girl's life is difficult», but she thinks that this is the case in "every sort of family and among all nationalities» and does not "know why ${ }^{39}$. In other words, she is aware that a girl suffers more than a boy, but this awareness is overshadowed by her worry about her poor family's survival.

Working class women may not develop a clear gender consciousness, as educated middle- and upper-class women may; however, they are more likely

33. In her Harem Years, Huda SHAARAwi also talks about how she publically took the veil off at Cairo train station in 1923; edited by Margot BADRAN, London, Virago, 1986.

34. Ibid., p. 68.

35. MernISSI, Fatima: Op. cit., p. 122. But of course the bad working conditions of the uneducated women force many of them, like Malika who weaves carpets, to accept a husband who can promise a more comfortable life for them, according to MernISSI.

36. ATIYA, Nayra: Op. cit., p. 22.

37. Ibid., p. 7.

38. Ibid., p. 14.

39. Ibid., pp. 17-18. 
to develop not only a maturer class consciousness than middle- and upperclass women, but also a feeling of solidarity with the women of, at least, their own class. In the absence of any form of health insurance at work, Dawiya alFilaliya, who works in a hand-made carpet workshop, speaks about how the women workers hide the sick ones in the middle of the wool and do their work so that the boss will not notice any reduction in production which is his main concern ${ }^{40}$. Alice, conscious of her middle class position, praises the working class's feeling of collectivity and readiness to unite and help each other, in contrast to middle class "selfishness» ${ }^{41}$.

Educated or uneducated, upper, middle, or working class, aware of their unjust conditions or not, class- or gender-conscious or both, these women do not speak about themselves independently from their respective families. The family/class position is the milieu within which these women tell their stories. The family remains the main social unit in all Arab countries. The extended family is the old form which still exists; however the new form, which consists of a married couple and their children only, is rapidly taking over in most Arab countries, especially in the cities.

Whether extended or not, the family still plays a controversial role in Arab women's lives. In the family, many if not most women experience the first forms of discrimination from their fathers and brothers. Yet at the same time for many women, these same figures (fathers and brothers) can be the first source of social protection and support. The father either symbolizes utter oppression for some, or is idealized by others, especially in his absence or more paradoxically, both simultaneously. The women in Khul-Khaal think that their lives could have been much better had their fathers been alive. The brother also can be either the source of more oppression, or more support and help, or both. If it was not for her brother who had to leave school and look for a paid job, Nazha Zannati and her children could have not survived after the death of her husband. Shaaban's brother, in contrast, caused her a lot of suffering. Thus, the women in the above anthologies weave their life stories around their families and their family relationships.

\subsection{Women Oppressing Other Women}

The male members of the family may very well be the first oppressors of women, nevertheless, the women themselves are not completely innocent of all blame and responsibility. For they themselves exercise some kind of discrimination and even oppression, one could say, upon their own daughters, thus perpetuating the very problem they have been suffering from. Twentyyear-old Leila, from Damascus, tells how her mother discriminates against her although she is her only daughter. The mother had herself rebelled against her own family and eloped with a man, and as a consequence was «cut off from

40. Mernissi, Fatima: Op. cit., p. 99.

41. AтזY, Nayra: Op. cit., p. 52. 
her social milieu». Yet, Leila comments, her mother loves her five sons while having a "nervous, erratic relationship» with her only daughter. Moreover, while stipulating to her sons that they could marry any woman of their own choice, the mother has tried to force her daughter into an arranged marriage, according to Leila. Leila tries to excuse her mother though, because she needed an outlet "and there was no-one around her on whom she could exercise authority except» Leila ${ }^{42}$.

Egyptian Om Gad was proud and happy when she had «four men» who «filled the house with their presence. Their comings and goings were my joy. They made me feel needed and gave me hope in the future ${ }^{43}$. But she does not mention anything special about her three daughters. Om Gad is a simple woman who might not see anything wrong with preferring boys to girls, perhaps because she sees everybody else so doing. But what excuse can Alice, a middle class educated woman, have when she admits that she prefers sons to daughters? Her marriage experience led to her «blind hatred» and "distrust» of all men and to regret that she ever married, as she repeats on many occasions, and she intelligently criticizes the social injustice against women in her society. She even seems to be conscious that preferring sons to daughters is not a very good thing, although she does not admit it overtly, for she says that there is one good thing to be said in her husband's favor, namely that he prefers daughters to sons ${ }^{44}$.

\subsection{Bodily Mutilation}

Preferring sons to daughters, or discriminating between them, is only one form of many ideological contradictions which are to be traced in almost every Arab woman's life. Arab feminists have yet to liberate themselves fully from all the effects caused by centuries of oppression. Ideological contradictions of this kind are materialized sometimes in physical forms of oppression such as the tradition of circumcision, which is still in practice in Egypt, the Sudan, and other African countries, among Muslims and Christians alike. Although a complete stranger to this tradition, I do not hesitate to call circumcision a mutilation of the female body. The five women in Khul-Khaal describe this "unforgettable» experience in its horrid details which I prefer not to quote here, because of their sickening effect. It is enough to say that Suda describes it as an "ordeal» and as "hell». All of the women were circumcised in the presence of their mothers, who in their turn had been circumcised too. Having gone through the pain and torture they so vividly remember, these women helped to pass the same experience to their daughters.

Alice recalls the experience with severe criticism. On the one hand, girls are brought up and prepared for their future role as wives who have the duty

42. SHAABAn, Bouthaina: Op. cit., pp. 69-70.

43. ATIYA, Nayra: Op. cit., p. 10.

44. Ibid., p. 42.

45. Ibid., p. 41. 
of sexually entertaining their husbands, on the other hand they themselves are not supposed to enjoy sex, for circumcision «makes it harder for a girl to enjoy sex", according to Alice ${ }^{45}$. Even Alice, however, took her eldest daughter to be circumcised although she went to a doctor to make it less painful for her, but when the doctor told her that the operation was illegal, she resorted to a midwife. But Alice did regret doing that, and saved her younger daughter who was fortunate enough to be born at a time when this operation was becoming less and less popular, especially in urban areas ${ }^{46}$.

The same operation is supposed not to affect women's sexual desires, according to $\mathrm{Om} \mathrm{Gad}$, although she still describes it with similar painful details as Alice and the other women do. For Om Gad thinks that an uncircumcised girl is «disfigured $»^{47}$. She does not say whether she was sexually affected or not. But even if she was not, this does not mean that Alice is wrong. Medical research has shown that circumcision does affect women's sexuality because the operation destroys very sensitive parts of the woman's sexual organs. One could argue that Muslim and Jewish boys are circumcised too. However, the effect of the operation has never been reported to have negatively affected men's sexuality in any way. On the contrary, boys are usually proud that they are circumcised. For them, it makes them clean and virile. Female circumcision is more painful and likely to lead to more infections and diseases because it is performed under no medical supervision.

Another kind of bodily mutilation, which I had never heard of until I read Khul-Khaal is the bride's deflowering by the hand. The Khul-Khaal women recall the disgust, pain and humiliation they felt when they were deflowered on their wedding night. In Arab and Muslim countries, the honor of the family is measured against the virginity of daughters before marriage. In some cases for a marriage to be complete, the bride's proof of virginity, a bed linen or a piece of cloth stained with her blood, has to be shown to everybody concerned. The convention of wedding parties in these countries has helped this tradition to continue. For wedding ceremonies, celebration and consummation take place in the bride's or bridegroom's parents' house, where the mothers of the wedded couple check the wedding bed in the morning. Until very recently, some brides have paid with their lives as punishment for failing the test. Some

46. The subject of female circumcision has been said to have caused political rows between Egypt and America after the CNN (American Television Network, which is one of the most widespread satellite television network world-wide) had broadcast and aired three times in one week a circumcision operation on a 10-year-old Egyptian girl. The CNN researcher was arrested in Cairo and charged with "distorting the image of Egypt». The Egyptian reaction is interesting to say the least. The $\mathrm{CNN}$ report has upset the Egyptian government although it is said to be campaigning against the practice of female circumcision. The documentary is "disgusting" according to al-Akhbar Egyptian newspaper, and the CNN should not have shown it especially after the «unlimited hospitality shown by the Ministry of Tourism to actress Jane Fonda, wife of CNN owner Ted Turner». Should hospitality and friendship be a pretext for concealing facts? See The Independent, 13th September 1994.

47. Ibid., p. 13. 
were pressured to commit suicide rather than live as outcasts for the rest of their lives.

This tradition, it must be said, is gradually dying. Arranged marriages are becoming less fashionable. A man and a woman can choose to marry anyone they want provided their respective families agree. Even when the families do not agree, a man and a woman can elope and get married somewhere else: Beirut was a place where lovers fled to when all other Arab countries were still very strict as far as marriages were concerned. Whether arranged or unarranged, wedding consummation no longer has to take place in the parents' house. People who can afford it travel for a honeymoon after the wedding party; in that case it is only the groom who decides what to do if he finds out that his bride is not a virgin. Today Arab men have different attitudes towards this issue. The question of women's virginity before marriage is still important to many. Some men do not marry women they have been in love with and slept with before marriage, on the grounds that a woman who sleeps with a man before marriage may also sleep with other men too before and after marriage- she would be considered loose. This is why some women who lose their virginity before marriage resort to a doctor who can amend their hymen just before the wedding is to take place. Again, women are exploited by these same doctors who charge them a great deal of money and blackmail them as well, for it is an illegal operation.

This discussion might seem a diversion, but it is not. The way the KhulKhaal women were deflowered must be one of the most traditionalist, and, I dare say, ugliest ways. The women were not even left alone with their husbands on the wedding night. The deflowering which was performed, using the finger, either by the husband himself or by an old woman relative was witnessed by a host of women relatives including the mothers of the bride and bridegroom. The main cultural contradiction here is that sex is one of the taboos in Arabic cultures, no-one would talk about sex publicly, especially within the family, yet the way the Khul-Khaal women are treated on their wedding nights makes it appear as if this sexual action were a public event. Moreover, this way of deflowering is a kind of mutilation because the women themselves describe it like this. Om Gad, at thirteen, had not yet developed breasts or menstruated, when she was married to a man twice her age. After the nauseating deflowering, she was left «limp» and "afraid», yet the husband went on mounting her all through the night ${ }^{48}$. Alice complained that she "was sore for about ten days» after her wedding night ${ }^{49}$.

The other two anthologies do not raise the issues of circumcision and deflowering, except for a brief reference to deflowering in Rabi'a's story. Answering Mernissi's question: "Did [your sister] accompany you in order to bring back the panties?» Rabi'a said: I wanted it to be done by a doctor». Rabi'a 
was married at a distance to a man in France. She traveled with her sister from Morocco for the marriage consummation. Someone has to bring back a proof of the bride's virginity when the marriage is consummated away from the parents, which is what Mernissi meant by "bring back the panties». I would not have understood Rabi'a's answer had I not read Khul-Khall. Rabi'a wanted her deflowering to be done by a doctor, because she was frightened. This reference indicates that the same tradition of hand deflowering is also practised in Morocco; however, the women in Doing Daily Battle did not talk about it, no doubt because they were not specifically asked to do so.

\subsection{Uncovering Sex and Sexuality}

The question is: would the Khul-Khaal women have spoken about circumcision and deflowering had they not been deliberately asked to? In Both Right and Left Handed, Shaaban herself ventures into uncovering lesbian practices among some Arab women. She writes about the women she has seen in a back room at the hairdresser's in Damascus. She also asks one of her interviewees whether she has thought of making love to her friend. Om Muhammad, an illiterate woman who had just celebrated her sixtieth birthday at the time of the interview, was married to a man who already had a wife. After some tension in the beginning, the co-wives became "friends». Om Muhammad was relieved when her husband «took the unilateral decision not to sleep with $[$ her $]{ }^{50}$. Answering Shaaban's question, Om Muhammad tells how one cold night she and her "friend» slept together and how much they enjoyed it:

"As usual, we felt close and intimate. Our legs touched, we hugged and we kissed each other, and suddenly our hearts started beating fast. We started panting, feeling all the warm blood in the world thrust into our veins $»^{51}$.

The women in Khul-Khaal do not speak about their own sexual desires. When they speak about sex, they refer to other women and seem to be inhibited about talking about their own sexuality. Om Gad thinks that women should be "reasonable» about sex, and that it is shameful for women to ask for sex. She complains that there are some women who

«just want a man all the time. Others don't. There are some women who want a man with them morning, noon, and night. If a night passes when he hasn't «bathed» with her, as we call it, she becomes angry, nervous, and ill-humoured, ${ }^{52}$.

It is also shameful for the woman in Suda's story who used to complain about her husband who had not slept with her for some time. She thought it was humiliating to ask for sex: "What can I do? Am I to sell myself? Do you think I can stoop so low as to say 'Come to me I want you? , $^{53}$. Suda tells the

50. SHAaban, Bouthaina: Op. cit., p. 63.

51. Ibid., p. 65.

52. AтাYA, Nayra: Op. cit., p. 13.

53. Ibid., p. 75.

54. Ibid., p. 79. 
story and sounds appalled when she comments that Egyptian women were obsessed with sex and money ${ }^{54}$. Sex, for women who are forced into marriages at an age when they do not even understand the meaning of the word, is perceived as no more than a marital duty. In Doing Daily Battle and in KhulKhaal most of the women were married before they had the chance to have any kind of love relationship. In that case, "sex is hateful, and a girl approaches it with fear», according to Alice ${ }^{55}$.

The inhibition about talking about one's own sexuality among workingclass women does not match the view expressed by middle and upper-class women of working-class women, who assume that working-class women are uninhibited about their bodies. This phenomenon can be explained as a result of not only having to work with other women during the day, because of poor working conditions, but also of sharing other bodily activities, such as bathing and sleeping, at home with other female members because of lack of enough space for each woman to have her own room. Lack of privacy at work and at home lessens some of the women's inhibitions about their bodies, without their necessarily losing inhibition about their own sexuality.

The lack of pre-marital love in these women's lives is not the only reason why sex is perceived as a burden (by Om Muhammad) or as shame (by Om Gad). The hardship of everyday life also contributes to limiting the sexual lives of these women. As Alice comments, women need to love, but also to be financially secure and bodily comfortable to be able to enjoy sex:

"When a woman has no problems in her life and she loves the man she is married to, then sex is a pleasure. But if there is struggle or daily hardship connected with any part of her life, she resists it. It becomes intolerable to her. There is no sweetness in loving if you are in financial straits ${ }^{56}$.

Most of the women in Doing Daily Battle have to work long hours in bad conditions in order to survive. Sex would not be the main issue in their life stories. It is significant that the only woman in Khul-Khaal, who spoke about sex -Alice- connected it with class position and is a middle class woman who, although a working mother, did not have to work long hours in bad conditions. The working class women by contrast did not make a big issue of sex. Om Gad, for example, seems to be more submissive about the whole issue; having gone through a painful deflowering on her wedding night, as she describes it, she simply got «used» to her husband demanding sex all that night.

Women like Om Gad do not seem to be aware that there is any kind of oppression in circumcision, hand deflowering or the institution of marriage as a whole. Circumcision is a tradition which many of them pass to their own daughters. Om Gad's main concern, as far as her daughters are concerned, is to "place [them] happily in some man's house " $^{77}$. Women like Om Gad, who 
believe strongly in traditions, do not see how their oppression as women could be different from that of the men of their own class. The similar bad conditions that both the men and the women of the working classes share make them brothers and sisters in suffering. Working class women's sympathetic attitude towards the men of their class seems to inhibit any awareness of distinct gender oppression being practised upon them. The lack of education and the belief in superstition and black magic, as we see in these anthologies, help these women to overlook their own suffering as women. It seems that women are more likely to be aware of their own oppression when they are educated and when they have the luxury of working and living in conditions that provide them with some kind of privacy and some spare time (privileges enjoyed by middle- and upper-class women). Education opens women's eyes to the falsity of many beliefs held as unquestionable traditions or else presents alternative values and life-styles, leading to inner conflict; and comfortable working and living conditions give them the time to think of themselves.

\subsection{Exchange of Women?}

Of equal importance to the women's differing educational and class positions is the historical process of economic changes and cultural shifts that allows older traditions and newer practices, older modes of thinking and newer ideals to co-exist in one society. The practice of male and female circumcision, but more particularly the practice of the semi-public deflowering can be seen as characteristic of marriage as a system of exchange between extended families. Such a system of exchange may be described as patriarchal in as much as the token of exchange is the female rather than the male body. The ritualistic significance attached to virginity and the much more drastic intervention in the female circumcision of the body, compared to male circumcision, reduce the young woman, more than the young man, to an object of value being exchanged.

The existing arranged marriages in Arab countries might be described as reminiscent of older times when the tribe or the extended family was (as it still is in some Gulf countries) the basic unit of the society. In such a society, the interest of the tribe or the family is above the individual's interest. The bodies of both men and women are completely taken up as social objects to enhance social alliance between families or tribes. A feminist reading is concerned with the much more drastic interventions and control of women's bodies evident in such practices as female circumcision, rather than with men's bodies, but the interrelatedness of the social control of women and men should be noted.

The idea of the exchange of women in marriage was discussed by Fredrich Engels in The Origin of the Family: Private Property and The State, (1884), and by Claude Levi-Strauss in The Elementary Structures of Kinship (first published in 1949). Engels argues that since antiquity, throughout the Middle Ages and up to modern times, marriage for the people who usually count as society (the free men and

58. Engels, Friedrich: The Origin of the Family: Private Property and the State, Harmondsworth, Penguin Books, 1985, p. 108. 
women, and later the feudal and then the bourgeois classes) has been «arranged by the parents and the partners calmly accept their choice $\aleph^{58}$. Marriage in this sense becomes «a contract, a legal transaction» by which women, especially, are exchanged. With the advancement of capitalism, the dependence of marriage on economic considerations has become complete: for the bourgeoisie, marriage «is a political act, an opportunity to increase power by new alliances; the interest of the house must be decisive, not the wishes of an individual ${ }^{59}$.

Claude Levi-Strauss, as a structuralist, also views the exchange of women in marriage as universal. In The Elementary Structures of Kinship, he sees women being treated, like words, as signs that can be exchanged. The difference is that women, unlike words, are persons and thus have a different kind of value. According to Levi-Strauss, women are seen

«under two incompatible aspects: on the one hand, as the object of personal desire, thus exciting sexual and proprietorial instincts; and, on the other, as the subject of the desire of others, and seen as such, i.e., as the means of binding others through alliance with them ${ }^{60}$.

The exchange of women, which he believes takes different forms, "direct or indirect, general or special, immediate or deferred, explicit or implicit, close or open, concrete or symbolic", acts to establish kinship structures ${ }^{61}$. LeviStrauss, of course, overlooks the role that women themselves play in such matchmaking arrangements. In some cases in Arabic societies, mothers are completely responsible for finding husbands for their daughters and fathers have only to approve of the mother's choices.

The attitude of older women and mothers, when they are eager to matchmake for their daughters and when they consciously or unconsciously perpetuate certain sexual practices, can be explained on two levels. On the economic level, these women are anxious that their daughters get married, for husbands are supposed to look after them. If circumcision is seen as necessary to guarantee husbands for their daughters, and if semi-public defloration is perceived as important to be sure of the honor and reputation of the family, then mothers have little choice in helping to practice them on their daughters. On the ideological level, the mental representation of material relations, mothers think that by preparing their daughters for acceptable marriages and by finding them what they see as suitable husbands, they are doing the best for them. Moreover, celibacy is discouraged in Islam. What is actually symbolized by turning the female body into a ritualistic object might have been forgotten, but the ritual is still significant as marking womanhood, even if paradoxically it also removes from women the possibility of sexual pleasure.

59. Ibid., p. 109.

60. Levi-Strauss, Claude: The Elementary Structures of Kinship, Rodney Needham (ed.), London, Eyre \& Spottiswoode, 1969, p. 496.

61. Ibid., pp. 478-479. 
Some Arab women are still being exchanged in arranged marriages, although the old significance of enforcing alliance between families might have been forgotten. This is not to decry all arranged marriages; the concept of exchanging women as objects and deciding their future partners for them doe not show respect to women. Love might not be a feminist issue for American or European women, but it certainly is for many Arab feminists, who until recently have not had the freedom of choice, in as much as choice implies having autonomy and control over one's own body. Some might argue that love, which is an individualistic conception and is glorified as the height of selfexpression and self-experience, is, yet again, an import from the west. This is simply not true, for love is one of the major themes glorified in Arabic literature for centuries. Lovers, in pre-Islamic poetry, though, were usually not allowed to marry each other, especially when their love became known in the tribe.

The opposition to marriages based on love matches, especially when they clash with the interests of the families concerned, was shared by western societies as well until the beginning of the twentieth century. Engels argues that throughout antiquity "love relationships in the modern sense only occur... outside the official society» ${ }^{62}$, that is among slaves ${ }^{63}$. Except among slaves, love affairs were found only as "products of the disintegration of the old world and carried on with women who also stand outside official society, with... foreigners or freed slaves». For free men and women, marriage "was arranged by the parents and the partners calmly accepted their choice» ${ }^{64}$. Love affairs occured among them but in the form of adultery, according to the same source. In the Middle Ages and in modern times, Engels has continued, marriage continues to be based on economic considerations rather than on individual and emotional relationships, especially among the upper classes. In twentieth-century societies, his distinction between bourgeois and working class marriages cannot be maintained because of the vast changes in social and economic structures. In Arabic societies today, the two systems, love matches and arranged marriages, are practiced side-by-side, especially where the nuclear family is taking over. In this case, changing consciousness and desires lead to conflict and make traditional practices look more problematic.

\section{CONCLUSION}

Khul-Khaal: Five Egyptian Women Tell Their Stories, Doing Daily Battle: Interviews With Moroccan Women and Both Right And Left Handed: Arab Women Talk About Their Lives are important mainly because they provide a voice for illiterate and working class women who otherwise would not have been heard nor represented. Although the life accounts or extracts in the above anthologies are not long enough to show self-reflection, there are signs of reflection in them.

62. EnGELS, Friedrich: Op. cit., p. 108.

63. Ibid., p. 108.

64. Ibid., p. 108. 
The women, especially the illiterate ones, have shown a desire for change, although they do not seem to be completely capable of it themselves. Instead, they see that some of their aspirations are achieved through their daughters. It is evident that change is taking place, even in Om Gad, the illiterate woman who seems to perpetuate certain oppressive traditions without questioning them. Her insistence on educating her daughters in itself is a conscious or at least semi-conscious admission of the need for change. Class consciousness may foreground gender consciousness in most illiterate and working class women, however with education spreading fast among younger generations of women in most Arab countries, gender oppression is becoming a major issue for them.

Change has not yet led to liberation; full liberation is yet to be achieved by even the most conscious feminists in Arab countries. The basic reason is that feminist consciousness is not enough on its own to liberate women; adequate social, economic, legal and political revolutionary changes should take place too. The discussion of these anthologies has been predominantly based on the modes of production and modes of oppression, because of the way they are presented. This study of modes of self-representation has been limited both by the way in which the texts were produced and edited and by of the content. Examining images of self-construction in the interviewees' short accounts of their lives, which are responses to certain questions addressed to them by the editors/writers, was not possible. 